\title{
POTENTIAL RISK OF LOSSES IN MAIZE CAUSED BY Dichelops melacanthus (DALLAS) (HEMIPTERA: PENTATOMIDAE) IN BRAZIL
}

\author{
IVAN CRUZ ${ }^{1}$, RODOLFO BIANCO ${ }^{2}$ e ANA CAROLINA MACIEL REDOAN ${ }^{1}$ \\ ${ }^{1}$ Embrapa Corn and Sorghum, Sete Lagoas, MG, Brazil-ivan.cruz@embrapa.br, ana.redoan@yahoo.com.br \\ ${ }^{2}$ IAPAR, Londrina, PR, Brazil, rbianco@iapar.br
}

$\overline{\text { Revista Brasileira de Milho e Sorgo, v.15, n.3, p. 386-397, } 2016}$

\begin{abstract}
The incidence of the green belly stink bug, Dichelops melacanthus (Dallas) (Heteroptera: Pentatomidae), on maize crop in Brazil has increased with time, especially due to the continuous availability of food throughout the year. This insect causes injury to seedlings, killing them shortly after their emergence from the soil. If the plant survives, it is possible to see areas with necrotic lesion that increase in a transverse pattern on the sheet, with perforations on the leaves or tillers (side shoots). This pest is currently one of the most important to maize, in conventional and $B t$ hybrids. The research compared the behavior of theses cultivars infested by the green belly stink bug, D. melacanthus. Bt and conventional maize cultivars were evaluated in a protected environment (greenhouse) and only $B t$ maize was evaluated at field. Evaluations based on plant development and insect injury occurred after seven days of the infestation period. The results indicated variability among cultivars related to insect infestation, measured by a visual scale for damage determination and plant development. Grain yield obtained from infested plots was $6352.2 \mathrm{~kg} \mathrm{ha}^{-1}$ whereas in the noninfested plots was $8048.05 \mathrm{~kg} \mathrm{ha}^{-1}$, equivalent to an average reduction of $21.07 \%$.
\end{abstract}

Keywords: Plant damage, grain losses, green belly stink bug

\section{RISCO POTENCIAL DE PERDAS CAUSADAS POR Dichelops melacanthus (DALLAS) (HEMIPTERA: PENTATOMIDAE) EM MILHO NO BRASIL}

RESUMO - A incidência do percevejo barriga verde Dichelops melacanthus (Dallas) (Heteroptera: Pentatomidae) em milho no Brasil tem aumentado nos últimos anos, especialmente devido à disponibilidade de alimento o ano todo. A injuria provocada pelo inseto pode causar a morte da plântula reduzindo o número ideal de plantas na colheita. Se a planta sobrevive, é possível visualizar áreas necrosadas ou perfilhamento. A praga é atualmente uma das mais importantes do milho, tanto em cultivares convencionais como em cultivares Bt. A presente pesquisa comparou o comportamento destas cultivares em ambiente protegido (casa de vegetação) e no campo, avaliando a injuria provocada pela praga, o desenvolvimento da planta e a produtividade de grãos (campo). Os resultados indicaram variabilidade entre cultivares em relação à injuria e ao desenvolvimento da planta. O rendimento de grãos nas parcelas infestadas foi $6352,2 \mathrm{kgha}^{-1}$ enquanto que nas parcelas sem infestação a produtividade foi $8048,05 \mathrm{kgha}^{-1}$, o equivalente a uma redução média de $21,07 \%$.

Palavras-chave: Danos, perdas em rendimento de grãos, percevejo barriga-verde 
With the release and commercial use of genetically modified maize in Brazil (Bt maize) there was a significant reduction in the incidence of the main pest, the fall armyworm, Spodoptera frugiperda (Lepidoptera: Noctuidae). In addition to the direct effect of $B t$ maize on the pest leading to its death, the innovative technology brought another great benefit to agribusiness, which was the reduction for chemical placed in the environment, used almost entirely for fall armyworm control. Unfortunately, the current cultivars of $B t$ maize are not efficient for other insect species, so-called "non-target". These species reached sufficient population density to cause economic damage to conventional maize only under special circumstances, especially in areas where the main pest was not present, or when it was present with low populations, not requiring control measures. With the reduction of chemicals use on $B t$ maize against the fall armyworm, new species are occupying the niche left by $S$. frugiperda, especially the sucking insects, including the green belly stink bug, Dichelops melacanthus, causing direct damage to freshly emerged maize.

Reduction of the use of agrochemicals and cultivation in a second crop season (Panizzi, 1997) are the main reasons for increasing the incidence of D. melacanthus in the initial stage of development of maize and wheat crops.

D. melacanthus damaging in maize seedlings was initially reported in the state of Mato Grosso do Sul; since then, its attack has increased year by year throughout the State. Nowadays, the geographical distribution of the insect also encompasses several other Brazilian States, including Parana, Santa Catarina, Rio Grande do Sul, Mato Grosso and southeast region of the State of São Paulo (Ávila \& Panizzi, 1995).
Bioecology, damage and control methods were reported by Ávila and Panizzi (1995), Martins and Weber (1998); Gomez (1998), Chocorosqui (2001), Chocorosqui and Panizzi, (2004), Ceccon et al. (2004), Albuquerque et al. (2006), Martins et al. (2006, 2009), Carvalho (2007), Roza-Gomes et al. (2011). During feeding, D. melacanthus places in a longitudinal position of the maize plant, with the head facing the base of the plant, injecting saliva to facilitate the stylet penetration; the damaged leaves have holes with yellow halo and arranged in rows; when the plant does not die, the first leaves that emerge have streaks and transverse streaks. Plants with severe attack present dwarfism and some development of unproductive tillers (Cruz \& Bianco, 2001; Bianco, 1997, 2005).

The wide use of crop rotation in no-tillage systems favors the supply of food sources and survival conditions to the insect during adverse periods of the year (winter or dry season) under crop residues (Chocorosqui \& Panizzi, 2004; Carvalho, 2007). Especially in Brazil, another favorable factor which favors increases in the insect population is the cultivation of host plants in sequential crop, such as soybean, maize and wheat. According to Chocorosqui and Panizzi (2003), D. melacanthus bread on soybean but it is not an important pest of this crop; on the other hand, it does not colonize maize plants, despite adult insect causing severe damage to seedlings of this crop.

Dichelops furcatus, a key pest of soybean, bears much resemblance to the $D$. melacanthus species (Grazia, 1978; Panizzi et al., 2007) which is the most important pest for both maize and wheat (Chocorosqui \& Panizzi 2004; Manfredi-Coimbra et al., 2005).

The objective of this work was to evaluate the susceptibility of different maize cultivars (Bt and conventional) regarding the presence of the 
green belly stink bug, Dichelops melacanthus, in a protected environment (greenhouse), assessing the symptoms of damage and the plant development at the early stage growth, and to evaluate the effect of the insect on grain yield in the field. Although maize hybrids were evaluated carrying different $B t$ s events, it was considered that this characteristic is specific for chewers of the order Lepidoptera thus not influencing the results against $D$. melacanthus, a non-target sucking insect of $B t$ maize.

\section{Material and Methods}

Experiments were conducted in area of Embrapa Maize and Sorghum Research Center (19²7'14'S / 4409'25'W, $730 \mathrm{~m}$ above sea level) in Sete Lagoas, Minas Gerais State, Brazil. The seeds of each evaluated genotype were obtained from the holding companies without treatment with systemic insecticides that could interfere in the results.

The susceptibility of different maize cultivars (Bt and conventional) was evaluated under greenhouse and at field (only $B t$ maize), comparing plots with and without the presence of $D$. melacanthus, measuring the resulting damage by using a visual scale of injury, the development of the plant (height and weight of plant canopy) and grain yield. The adult stink bugs used in the experiments were from the colony kept in the laboratory. The relative growth of each cultivar was also evaluated by comparing the height or weight of the infested plant divided by the equivalent value of the non-infested plant multiplied by 100 .

\section{Greenhouse test}

Experiments were carried out under greenhouse, in a completely randomized design with 10 replications, each one represented by one plant, evaluating 15 different hybrids including $B t$ and conventional maize. Plastic pots with $4.5 \mathrm{~kg}$ of soil fertilized with $6 \mathrm{~g}$ of NPK 4-14-8 formulation immediately incorporated into the soil received the seeds of each cultivar. Infestation on ten plants of each genotype was accomplished one week after the emergence (V1 growth stage), placing one adult per plant. The insects stayed on plants for eight days. For comparison, identical number of plants without infestation was used. Screen-coated wire cage covered all plants during infestation period. Daily inspection indicated replacement of any dead insects inside the pots.

At the end of the infestation period, each plant was evaluated for its development and damage caused by the pest using a visual scale, assigning zero to the absence of visible injury, one to mild injury, two to medium injury and three to severe injury (Bianco, 2005). A second evaluation was performed one week after the first, assigning the same scale of damage. Additionally, after the second evaluation we take the fresh weight from eight plants newly removed from the soil.

\section{Field test}

Only Bt maize cultivars were evaluated at field condition in a savanna area, using a randomized complete block design with split plots. Each plot with $B t$ cultivars was five-meter-long rows, spaced $0.70 \mathrm{~m}$. As fertilizer, $400 \mathrm{~kg} \mathrm{ha}^{-1}$ of the commercial formula 8-28-16 + Zn was used. Three field experiments were carried out, with planting dates on February 21, 2014, January 9 and 28, 2015. Additional irrigation was used when necessary. The subplots comprised plants without infestation and plants infested by 
one D. melacanthus per plant (one week after the emergence - V1 growth stage). The plots without and with the insects were covered by iron cages and fine screens throughout the period of infestation (two cages/subplot). Such cover remained on the plants for a period of seven days, after which the plants were visually evaluated for insect damage, using the same scale mentioned in the greenhouse experiment.

\section{Statistical analysis}

For both greenhouse and field experiments the statistical analyzes (Analysis of Variance and mean separation) were performed with the free software SISVAR (Ferreira, 2014).

\section{Results Greenhouse test}

The cultivars AG 8088 and P 30F35 YH showed the lowest values in the visual damage scale (average of 0.8). On the opposite side, the highest damage score was attributed to two $B t$ cultivars (AG 8088 YG and AG 8088 PRO 2) and to a conventional cultivar (P 30F35), with an average of 2.47. Relatively high average damage (1.7) was attributed to cultivars DKB 390 YG, P 3646 H, 2B707 Hx, DKB 330 YG and DOW 2B587, the latter, a conventional cultivar. Finally, cultivars DOW 30A16 Hx, DOW 2B587 Hx, AG 8088 PRO, DOW 30A16 and P 30F53 scored a mean damage of 1.46 . The results indicate variability among maize cultivars concerning insect injury (Table1), regardless the cultivar type.

Infested plants showed an average height of $41.43 \mathrm{~cm}$, a value significantly lower than that presented by non-infested cultivars $(51.74 \mathrm{~cm})$, corresponding to $20 \%$ height reduction when under insect feeding. There was interaction between cultivar and infestation. The two cultivars (AG 8088 and $\mathrm{P} 30 \mathrm{~F} 35 \mathrm{YH}$ ) that presented the lowest damage scale values under infestation did not present reduced development compared to no-infested plants (Table 1). The same situation occurred with the cultivar AG 8088 PRO; no significant reduction in development was observed during the feeding period by the insect compared to the development of plants without infestation. All other cultivars showed significantly reduction of plant development when infested by $D$. melacanthus.

Table 1 shows the relative height of the plants, as the measurement from the base of the plant to the apex of the longest leaf. The mean height of the infested plant in relation to the height of the noninfested plant ranged from 51.24 to $98.54 \%$. Infested plants of cultivars AG 8088 and P 30F35 YH showed the lowest scores of injuries (0.80), with $95.5 \%$ of the average height of the plants without infestation. In other words, in these two cultivars the average reduction in plant height was $4.5 \%$. For the group of cultivars with average visual damage of 1.46 (DOW 30A16 Hx, DOW 2B587 Hx, AG 8088 PRO, DOW $30 \mathrm{~A} 16$ and P 30F53), the relative height of the infested plants ranged from 68.09 to $91.22 \%$ of the value presented by the non-infested plants, suggesting differentiated reaction of the cultivars. The average size of the cultivar DOW 2B587 Hx with a damage score of 1.40 was only $68.09 \%$ of that presented by the same cultivar without infestation, therefore a reduction of $42 \%$. This value was significantly different from the value of the other cultivars in the group, whose reduction in plant size was $10.72 \%$.

With the increase in the level of injury caused by the pest, as occurred in the cultivars with an average visual damage of 2.06 , the relative height 
of the infested plant ranged from 71.08 to $87.93 \%$ of the height of the non-infested plants. In this group, despite the similar damage, the relative height of the plant varied with the cultivar, being significantly similar for cultivars DKB 390 YG and DOW 2B587, with an average plant height reduction of $14.47 \%$. For cultivars P $3446 \mathrm{H}, 2 \mathrm{~B} 707 \mathrm{Hx}$ and DKB 330 $\mathrm{YG}$, with similar relative plant growth, the average reduction was $26.54 \%$ compared to the average plant height without infestation. The cultivars AG 8088 PRO 2 and AG 8088 YG were also included in this latter group, with a mean damage score of 2.5 , but with an average reduction in plant growth of $25.1 \%$. A reduction of $48.76 \%$ in the development of the plant was observed in the cultivar P 30F35 whose visual damage score was also one of the largest (2.60), indicating its susceptibility to injury caused by the green belly stink bug (Table 1 ).

Table 2 shows the height of the plant seven days after the interruption of the feeding period by the insect. Probably there was no enough time for plant recovery due to the short period between absence of feeding and the second evaluation. There was no significant difference in plant development, except for two cultivars. The height of the cultivar P $30 \mathrm{~F} 35 \mathrm{Hx}$ decreased $7.46 \%$ and $55.15 \%$ in the first and second evaluation periods, respectively. On the other hand, cultivar P $30 \mathrm{~F} 35$ presented a reduction of $48.76 \%$ of plant development in the first evaluation which was partially recovered during the subsequent period of seven days without the presence of the insect with a reduction in the development of $21.39 \%$. Considering only the cultivars with average visual damage equal to or greater than 1.9 , the average reduction in plant development was $30.2 \%$.

Although unlikely to be evaluated in the field once it is a destructive method, Table 2 also shows the relative weight of the plant canopy, that is, the percentage ratio between the weight of the infested plant and the equivalent weight of the non-infested one. Plants under attack of the green belly stink bug weighted from 40.91 to $83.13 \%$ of the green mass produced by plants without infestation.

Statistically, two groups of cultivars were differentiated in the evaluation of the fresh mass of plant canopy (Table 2). In the first group, the cultivars AG 8088 (C), DOW 30A16 Hx, P 30F53 (C), AG 8088 PRO, DOW 30A16 (C), P 3646 H, DOW 2B587 (C), DKB390 YG and P 30F35 Hx were the cultivars with the lowest reduction in mass, that is, with the green mass closer to the verified for the same cultivar in the absence of infestation. Four of the five conventional cultivars (C) evaluated are included in this group. On average, the green mass of this first group of cultivars was $73.9 \%$ of the values obtained for the cultivars without infestation. In other words, an average decrease of $26.13 \%$.

The second group of cultivars, which showed higher fresh green mass reduction after being injured by the pest, included P 30F35 (C), DOW 2B587 Hx, DOW 2B707 Hx, AG 8088 PRO 2, DKB330 YG and $A G 8088 \mathrm{YG}$ ), with an average of $49.90 \%$ in the production of green mass when plants were under attack by $D$. melacanthus.

Experiments carried out in a greenhouse are important to indicate the behavior of the pest related to different host plants in a relatively short time period. In this first experiment, the importance of the insect for maize was clear regardless the cultivar, conventional or $B t$-expressing. For a continuous period of seven days with the insect feeding on plant, a reduction in the development was observed, measured by the size and weight of the crop canopy. In general, all evaluated cultivars showed to be a food source for the 
Table 1. Response of $B t$ and conventional (C) maize hybrids to the injury of Dichelops melacanthus in greenhouse test: damage and plant height ${ }^{1}$.

\begin{tabular}{|c|c|c|c|c|}
\hline \multirow{3}{*}{ Cultivars } & \multirow{3}{*}{$\begin{array}{l}\text { Damage on } \\
\text { infested } \\
\text { plots }\end{array}$} & \multirow{2}{*}{\multicolumn{2}{|c|}{$\begin{array}{l}\text { Plant height }(\mathrm{cm}) \text {, seven } \\
\text { days after infestation }{ }^{1}\end{array}$}} & \multirow{3}{*}{ Relative Plant Height (RPH) ${ }^{2}$} \\
\hline & & & & \\
\hline & & Non-infested & Infested & \\
\hline AG 8088 (C) & $0.70 \mathrm{D}$ & $50.80 \mathrm{a}$ & $50.00 \mathrm{a}$ & $98.54 \mathrm{~A}$ \\
\hline P 30F35 YH & $0.90 \mathrm{D}$ & $56.60 \mathrm{a}$ & $52.40 \mathrm{a}$ & $92.46 \mathrm{~A}$ \\
\hline DOW 30A16 Hx & $1.30 \mathrm{C}$ & $73.20 \mathrm{a}$ & $64.80 \mathrm{~b}$ & $89.01 \mathrm{~A}$ \\
\hline DOW 2B587 Hx & $1.40 \mathrm{C}$ & $58.20 \mathrm{a}$ & $39.50 \mathrm{~b}$ & 68.09B \\
\hline Ag 8088 PRO & $1.50 \mathrm{C}$ & $38.50 \mathrm{a}$ & $34.96 \mathrm{a}$ & $91.22 \mathrm{~A}$ \\
\hline DOW 30A16 (C) & $1.50 \mathrm{C}$ & $62.70 \mathrm{a}$ & $55.95 b$ & $89.49 \mathrm{~A}$ \\
\hline P 30F53 (C) & $1.60 \mathrm{C}$ & $39.79 \mathrm{a}$ & $34.57 b$ & $87.40 \mathrm{~A}$ \\
\hline DKB $390 \mathrm{YG}$ & $1.90 \mathrm{~B}$ & $40.77 \mathrm{a}$ & $35.74 b$ & $87.93 \mathrm{~A}$ \\
\hline P $3646 \mathrm{H}$ & $1.90 \mathrm{~B}$ & $53.50 \mathrm{a}$ & $37.15 b$ & 71.08B \\
\hline 2B707 Hx & $2.10 \mathrm{~B}$ & $59.40 \mathrm{a}$ & $42.45 b$ & $71.51 \mathrm{~B}$ \\
\hline DKB $330 \mathrm{YG}$ & $2.14 \mathrm{~B}$ & $37.24 \mathrm{a}$ & $28.30 \mathrm{~b}$ & 77.79B \\
\hline DOW 2B587 (C) & $2.25 \mathrm{~B}$ & $63.50 \mathrm{a}$ & $52.63 b$ & $83.13 \mathrm{~A}$ \\
\hline AG 8088 PRO 2 & $2.43 \mathrm{~A}$ & $58.73 \mathrm{a}$ & $43.63 b$ & $74.22 \mathrm{~B}$ \\
\hline AG 8088 YG & $2.56 \mathrm{~A}$ & $33.03 \mathrm{a}$ & $23.74 b$ & $75.58 \mathrm{~B}$ \\
\hline P 30F35 (C) & $2.60 \mathrm{~A}$ & $50.15 \mathrm{a}$ & $25.60 \mathrm{~b}$ & $51.24 \mathrm{C}$ \\
\hline Average & & $51.74 \mathrm{a}$ & $41.43 b$ & \\
\hline
\end{tabular}

pest. Especially for $B t$ maize cultivars, whose main target in Brazil is the fall armyworm, Spodoptera frugiperda, the susceptibility of the plant to the green belly stink bug can undoubtedly raise the cost of crop production when demanding control measures.

\section{Field experiment 1}

In the first field experiment, the plant heights were on average $16.68 \mathrm{~cm}$ on the same day of infestation, with no significant difference between plots to be infested and those that would be.

Evaluating of the reaction of the plant to the injury caused by insect feeding, an uniformity among cultivars was observed in the scale of zero (without visible damage) to three (severe damage), with no significant difference between treatments and a mean damage score of 1.73 . This evaluation was performed after a period of seven days of feeding (Table 3). Similarly, no significant difference in plant size reduction was detected, with an average of $11.27 \%$. There was no cultivar $\mathrm{x}$ infestation interaction, but a significant difference between infested and non-infested plants was observed for all cultivars.

The average grain yield of the non-infested cultivars was $7512.15 \mathrm{~kg} \mathrm{ha}^{-1}$, significantly higher than the average of $6052.34 \mathrm{~kg} \mathrm{ha}^{-1}$ observed for the 
Table 2. Effect of Dichelops melacanthus feeding on plant height and weight of Bt or conventional (C) maize cultivars in greenhouse test ${ }^{1}$.

\begin{tabular}{|c|c|c|c|c|}
\hline \multirow{3}{*}{ Cultivars } & \multirow{2}{*}{\multicolumn{2}{|c|}{$\begin{array}{l}\text { Plant height }(\mathrm{cm}) \text { seven days after the } \\
\text { interruption of the feeding period } \\
\text { Infestation }\end{array}$}} & \multirow{3}{*}{$\begin{array}{l}\text { Relative Plant } \\
\text { Height }(\mathrm{RPH})^{2}\end{array}$} & \multirow{3}{*}{$\begin{array}{l}\text { Relative Plant } \\
\text { Weight (RPW) }\end{array}$} \\
\hline & & & & \\
\hline & Non-infested & Infested & & \\
\hline AG $8088(C)$ & $62.00 \mathrm{a}$ & $62.30 \mathrm{a}$ & $101.03 \mathrm{~A}$ & $78.86 \mathrm{~A}$ \\
\hline DOW 30A16 Hx & $91.40 \mathrm{a}$ & $85.30 \mathrm{a}$ & $93.59 \mathrm{~A}$ & $76.84 \mathrm{~A}$ \\
\hline P 30F53 (C) & $53.60 \mathrm{a}$ & $47.50 \mathrm{a}$ & $89.14 \mathrm{~A}$ & 75.97A \\
\hline AG 8088 PRO & $53.60 \mathrm{a}$ & $54.50 \mathrm{a}$ & $103.43 \mathrm{~A}$ & $71.20 \mathrm{~A}$ \\
\hline DOW 30A16 (C) & $83.10 \mathrm{a}$ & $72.30 \mathrm{~b}$ & $87.16 \mathrm{~A}$ & $72.36 \mathrm{~A}$ \\
\hline P $3646 \mathrm{H}$ & $63.30 \mathrm{a}$ & $41.20 \mathrm{~b}$ & $65.57 \mathrm{~B}$ & $67.51 \mathrm{~A}$ \\
\hline P 30F35 (C) & $77.00 \mathrm{a}$ & $60.50 \mathrm{~b}$ & $78.61 \mathrm{~B}$ & 40.91B \\
\hline DOW 2B587 (C) & $86.43 a$ & $57.71 b$ & $67.10 \mathrm{~B}$ & $83.13 \mathrm{~A}$ \\
\hline DKB390 YG & $61.40 \mathrm{a}$ & $45.50 \mathrm{~b}$ & $73.95 \mathrm{~B}$ & $72.50 \mathrm{~A}$ \\
\hline DOW 2B587 Hx & $72.00 \mathrm{a}$ & $46.00 \mathrm{~b}$ & $64.28 \mathrm{~B}$ & $58.59 \mathrm{~B}$ \\
\hline DOW 2B707 Hx & $75.10 \mathrm{a}$ & $50.60 \mathrm{~b}$ & $66.92 \mathrm{~B}$ & $63.06 \mathrm{~B}$ \\
\hline AG 8088 PRO 2 & $78.17 \mathrm{a}$ & $58.33 b$ & 74.47B & $52.49 \mathrm{~B}$ \\
\hline P 30F35 Hx & $59.90 \mathrm{a}$ & $26.60 \mathrm{~b}$ & $44.45 \mathrm{C}$ & $66.42 \mathrm{~A}$ \\
\hline DKB330 YG & $53.70 \mathrm{a}$ & $34.60 \mathrm{~b}$ & $64.76 \mathrm{~B}$ & 49.95B \\
\hline AG $8088 \mathrm{YG}$ & $51.40 \mathrm{a}$ & $32.40 \mathrm{~b}$ & $67.42 \mathrm{~B}$ & $48.57 \mathrm{~B}$ \\
\hline
\end{tabular}

Average $68.14 \mathrm{a}$ $51.69 \mathrm{~b}$

${ }^{1}$ Means followed by the same capital letter in the column and lowercase in the row do not differ significantly from each other by the Scott-Knott test (5\%)

${ }^{2} \mathrm{RPH}$ or RPW: height or weight of the infested plant divided by the equivalent value of the non-infested plant multiplied by 100 .

infested cultivars. There was no interaction between cultivar and infestation. Comparatively, there was no significant difference in grain yield reduction between cultivars, with an average of $19.65 \%$

\section{Field experiment 2}

In the second field experiment, the plants showed on average $9.8 \mathrm{~cm}$ at the time of infestation and no significant difference between plots to be infested or not infested by the insect, similarly to the first experiment. The injury caused by the insect to plants represented mean damage scores ranging from 0.78 to 2.67 (Table 4). The lowest mean, attributed to cultivar $\mathrm{P} 2830 \mathrm{H}$, was significantly different from the others. On the opposite side, the cultivars P3646YH C2, P3862 $\mathrm{YH}$ and $\mathrm{P} 3844 \mathrm{H}$ presented greater injuries, averaging 2.28.

Estimated grain yield of the cultivars was similar in the absence of the insect, with an average of $8126.57 \mathrm{~kg} \mathrm{ha}^{-1}$. In the presence of the pest, the grain yield was only $5677.86 \mathrm{~kg} \mathrm{ha}^{-1}$. The grain yield of all cultivar under infestation was significantly lower than the yield of non-infested cultivars (Table 4 ), and the yield reduction did not vary among the cultivars, with a mean of $33.34 \%$, showing the importance of the pest in the crop system of Bt maize. 
Table 3. Effect of Dichelops melacanthus feeding on plant height, plant weight and grain yield of $B t$ maize cultivars at field. Experiment 1.

\begin{tabular}{lccccc}
\hline \multirow{2}{*}{ Cultivar } & $\begin{array}{c}\text { Damage } \\
\text { on infested } \\
\text { plots }^{2}\end{array}$ & $\begin{array}{c}\text { Reduction in } \\
\text { plant height } \\
(\%)\end{array}$ & \multicolumn{2}{c}{$\begin{array}{c}\text { Grain yield }\left(\mathrm{kg} \mathrm{ha}^{-1}\right)^{1} \\
\text { Infestation }\end{array}$} & $\begin{array}{c}\text { Reduction in grain } \\
\text { yield (\%) }\end{array}$ \\
\hline P 30R50H & $1.65 \mathrm{~A}$ & $12.95 \mathrm{~A}$ & $8874.47 \mathrm{a}$ & $6310.94 \mathrm{a}$ & $27.00 \mathrm{~A}$ \\
DKB390 PRO 2 RR & $1.85 \mathrm{~A}$ & $7.34 \mathrm{~A}$ & $7518.75 \mathrm{a}$ & $6743.75 \mathrm{a}$ & $14.75 \mathrm{~A}$ \\
P 30F35 HR & $1.70 \mathrm{~A}$ & $12.18 \mathrm{~A}$ & $6925.00 \mathrm{a}$ & $5400.00 \mathrm{a}$ & $21.33 \mathrm{~A}$ \\
DOW 30A16 HX & $1.67 \mathrm{~A}$ & $14.46 \mathrm{~A}$ & $7460.94 \mathrm{a}$ & $6293.75 \mathrm{a}$ & $13.16 \mathrm{~A}$ \\
AG 8088 PRO 2 RR & $1.78 \mathrm{~A}$ & $9.77 \mathrm{~A}$ & $7268.75 \mathrm{a}$ & $5703.12 \mathrm{a}$ & $24.98 \mathrm{~A}$ \\
AG 8088 VT PRO & $1.75 \mathrm{~A}$ & $10.94 \mathrm{~A}$ & $7025.00 \mathrm{a}$ & $5862.50 \mathrm{a}$ & $16.64 \mathrm{~A}$ \\
\hline Average & 1.73 & 11.27 & $7512.15 \mathrm{a}$ & $6052.34 \mathrm{~b}$ & 19.65 \\
\hline
\end{tabular}

${ }^{1}$ Means followed by the same capital letter in the column and lowercase in the row do not differ significantly from one another by the Scott-Knott test (5\%).

${ }^{2}$ Seven days after infestation.

Table 4. Plant damage, grain yield and yield reduction caused by Dichelops melacanthus in different cultivars of $B t$ maize. Field experiment 2.

\begin{tabular}{lcccc}
\hline \multirow{2}{*}{ Cultivar } & $\begin{array}{c}\text { Average damage score } \\
\text { on infested plots }\end{array}$ & \multicolumn{2}{c}{$\begin{array}{c}\text { Grain yield }\left(\mathrm{kg} \mathrm{ha}^{-1}\right)^{1} \\
\text { Infestation }\end{array}$} & $\begin{array}{c}\text { Reduction in grain } \\
\text { yield (\%) }\end{array}$ \\
\cline { 2 - 4 } & $0.78 \mathrm{C}$ & $7882.14 \mathrm{a}$ & $5907.14 \mathrm{~b}$ & $23.92 \mathrm{~A}$ \\
P 2830H & $2.67 \mathrm{~A}$ & $8528.57 \mathrm{a}$ & $4382.14 \mathrm{~b}$ & $46.26 \mathrm{~A}$ \\
P 3646YH C2 & $2.18 \mathrm{~A}$ & $7471.43 \mathrm{a}$ & $5953.57 \mathrm{~b}$ & $29.89 \mathrm{~A}$ \\
P 3862 YH & $1.99 \mathrm{~A}$ & $8496.43 \mathrm{a}$ & $6046.43 \mathrm{~b}$ & $32.73 \mathrm{~A}$ \\
P 3844H & $1.48 \mathrm{~B}$ & $8254.29 \mathrm{a}$ & $6100.00 \mathrm{~b}$ & $33.91 \mathrm{~A}$ \\
30F53Y HR & & $8126.57 \mathrm{a}$ & $5677.86 \mathrm{~b}$ & \\
\hline Average & & &
\end{tabular}

${ }^{1}$ Means followed by the same capital letter in the column and lowercase in the row do not differ significantly from one another by the Scott-Knott test (5\%).

\section{Field experiment 3}

In the experiment 3 (Table 5), plant height was evaluated seven days after infestation. There was no interaction between cultivar and infestation. Furthermore, there was no significant difference between means of heights from non-infested or infested plants. The climatic conditions favored a faster development of the plants. There was no significant difference between the infested cultivars concerning the visual damage, with a mean of 1.4. Despite the relatively lower damage than that observed in the previous experiment, infested plants also showed significantly lower yield of grains than plants without infestation. There was no interaction between infestation and cultivars and the grain yield of the infested plants $\left(7326.43 \mathrm{~kg} \mathrm{ha}^{-1}\right)$ was significantly lower than the grain yield from non- 
Table 5. Plant damage, plant height, grain yield and yield reduction caused by Dichelops melacanthus in different cultivars of $B t$ maize. Field experiment 3.

\begin{tabular}{|c|c|c|c|c|c|c|}
\hline \multirow{3}{*}{ Cultivar } & \multirow{3}{*}{$\begin{array}{c}\text { Average } \\
\text { damage score } \\
\text { on infested } \\
\text { plots }\end{array}$} & \multirow{2}{*}{\multicolumn{2}{|c|}{$\begin{array}{l}\text { Plant height seven days after } \\
\text { infestation }(\mathrm{cm})^{1} \\
\text { Infestation }\end{array}$}} & \multicolumn{2}{|c|}{ Grain yield $\left(\mathrm{kg} \mathrm{ha}^{-1}\right)^{1}$} & \multirow{3}{*}{$\begin{array}{c}\text { Reduction in } \\
\text { grain yield (\%) }\end{array}$} \\
\hline & & & & Inf & station & \\
\hline & & $\begin{array}{c}\text { Non- } \\
\text { infested }\end{array}$ & Infested & $\begin{array}{c}\text { Non- } \\
\text { infested }\end{array}$ & Infested & \\
\hline $\mathrm{P} 2830 \mathrm{H}$ & $1.36 \mathrm{~A}$ & $41.57 \mathrm{a}$ & $42.14 \mathrm{a}$ & $7703.57 a$ & $6903.57 b$ & $20.63 \mathrm{~A}$ \\
\hline P3646YH C2 & $1.38 \mathrm{~A}$ & $34.55 \mathrm{a}$ & $32.50 \mathrm{a}$ & $8864.29 \mathrm{a}$ & $6821.43 b$ & $22.51 \mathrm{~A}$ \\
\hline P3862 YH & $1.48 \mathrm{~A}$ & $35.32 \mathrm{a}$ & $36.77 \mathrm{a}$ & $9821.43 a$ & $8585.71 b$ & $15.44 \mathrm{~A}$ \\
\hline P3844H & $1.30 \mathrm{~A}$ & $47.74 \mathrm{a}$ & $46.93 \mathrm{a}$ & $7945.00 \mathrm{a}$ & $8160.71 b$ & $16.29 \mathrm{~A}$ \\
\hline 30F53Y HR & $1.46 \mathrm{~A}$ & $35.70 \mathrm{a}$ & $35.36 \mathrm{a}$ & $8192.86 \mathrm{a}$ & $6160.71 b$ & $26.45 \mathrm{~A}$ \\
\hline Average & 1.40 & $38.98 \mathrm{a}$ & $38.74 \mathrm{a}$ & $8505.43 a$ & $7326.43 b$ & \\
\hline
\end{tabular}

${ }^{1}$ Means followed by the same capital letter in the column and lowercase in the row do not differ significantly from one another by the Scott-Knott test (5\%).

infested plants. The reduction in grain yield of infested plots compared to non-infested plots was not significantly different among cultivars, with an overall mean was $20.26 \%$.

\section{Discussion}

The losses caused by D. melacanthus are related to the stage of development of the maize plant, which can be verified by a visual scale of damage (Brustolin et al., 2011), dry weight of the plant canopy or grain yield evaluations. The insect normally attacks on seedling stage between one and five leaves (Duarte et al., 2015). According to these authors, plants infested at the growth stages V4 and V5 did not show reduction in grain yield compared to plants without infestation. According to Slansky and Panizzi (1987) and Hori (2000), the highest susceptibility of maize seedlings to the injury of $D$. melacanthus is due to the inoculation in the plant of indole-3-acetic acid, a very toxic compound at the beginning of plant development. Albuquerque et al. (2006) suggested that the use of curative measures for pest control eight days after emergence of the plants is too late to avoid economic damages caused by the insects. Netto et al. (2015) also demonstrated the importance of the insect, emphasizing the reduction in plant height and grain yield of $B t$ and conventional maize plants under infestation with one adult insect per plant for a feeding period of 15 days, beginning three days after the plant emergence. Netto et al. (2015) use the same insect density of the present study, but the plants remained under the action of the pest for a much longer period and earlier. Although there are reports of the possibility of death of the seedling attacked by the insect (Ávila \& Panizzi, 1995; Viana et al., 2001) in the present work no death was verified; possibly this fact can be explained by the high genetic quality of the current maize hybrids available in the Brazilian market.

Considering all cultivars evaluated in the field (Tables 3-5), without the presence of the insect the yield was $8048.43 \mathrm{~kg} \mathrm{ha}^{-1}$; whereas, in the presence of the insect grain yield was $6352.21 \mathrm{~kg} \mathrm{ha}^{-1}$, a difference 
of $21.07 \%$ or $1696,22 \mathrm{~kg} \mathrm{ha}^{-1}$. According to the results of Duarte et al. (2015), the relationship between grain yield and pest density follows inversely the firstdegree equation; the estimated yield was $2409.65 \mathrm{~kg}$ $\mathrm{ha}^{-1}$ for the density of one green belly stink bug per plant and $2785 \mathrm{~kg} \mathrm{ha}^{-1}$ in the absence of the insect. In other words, a loss of $375.35 \mathrm{~kg} \mathrm{ha}^{-1}$, or equivalent to a reduction of $13.48 \%$ in grain yield, which represents values significantly lower than the obtained in the present work. Maize plants damaged by the insect presented reduced development and became less competitive for water and nutrients uptake.

\section{Conclusions}

Variability occurs between maize cultivars as response to the injury caused by the insect, evaluated by a visual scale, and can be used for a rapid selection of cultivars in protected environment as a greenhouse.

Cultivars of maize and insect infestation can interact with development of the plant (plant height and weight of the canopy). However, no interaction was observed with grain yield.

\section{References}

ALBUQUeRQue, F. A.; BORGES, L. M.; IACONO, T. O.; CRUBELATI, N. C. S.; SINGER, A. C. Eficiência de inseticidas aplicados em tratamento de sementes e em pulverização, no controle de pragas iniciais do milho. Revista Brasileira de Milho e Sorgo, Sete Lagoas, v. 5, n. 1, p. 15-25, 2006.

DOI: 10.18512/1980-6477/rbms.v5n1p15-25.

ÁVILA, C. J.; PANIZZI, A. R. Occurrence and damage by Dichelops (Neodichelops) melacanthus (Dallas)
(Heteroptera: Pentatomidae) on corn. Anais da Sociedade Entomológica do Brasil, Londrina, v. 24, p. 193-194, 1995.

BIANCO, R. Ocorrência e manejo de pragas em plantio direto. In: PEIXOTO, R. T. G.; AHRENS, D. C.; SAMAHA, M. J. (Ed.). Plantio direto: o caminho para uma agricultura sustentável. Ponta Grossa: IAPAR, 1997. p. 238-244.

BIANCO, R. O percevejo barriga verde no milho e no trigo em plantio direto. Revista Plantio Direto, Passo Fundo, v. 15, n. 89, p. 46-51, 2005.

BRUSTOLIN, C.; BIANCO, R.; NEVES, P. M. O. J. Inseticidas em pré e pós-emergência do milho (Zea mays L.) associados ao tratamento de sementes, sobre Dichelops melacanthus (Dallas) (Hemiptera: Pentatomidae). Revista Brasileira de Milho e Sorgo, Sete Lagoas, v. 10, p. 215 223, 2011.

DOI: $10.18512 / 1980-6477 /$ rbms.v10n3p215-223.

CARVALHO, E. S. M. Dichelops melacanthus (Dallas, 1851) (Heteroptera: Pentatomidae) no sistema de plantio direto no sul do Mato Grosso do Sul: flutuação populacional, hospedeiros e parasitismo. 2007. $57 \mathrm{f}$. Dissertação (Mestrado) - Universidade Federal da Grande Dourados, Dourados, 2007.

CECCON, G.; RAGA, A.; DUARTE, A. P.; SILOTO, R. C. Efeito de inseticidas na semeadura sobre pragas iniciais e produtividade de milho safrinha em plantio direto. Bragantia, Campinas, v. 63, n. 2, p. 227-237, 2004. DOI: $10.1590 / \mathrm{S} 0006-87052004000200008$.

CHOCOROSQUI, V. R. Bioecologia de Dichelops (Diceraeus) melacanthus (Dallas, 1851) (Homoptera: Pentatomidae), danos e controle em soja, milho e trigo no norte do Paraná. 2001. 160 f. Tese (Doutorado em Ciências) - Universidade Federal do Paraná, Curitiba, 2001.

CHOCOROSQUI, V. R.; PANIZZI, A. R. Photoperiod influence on the biology and phenological characteristics of Dichelops melacanthus (Dallas, 1851) (Heteroptera: 
Pentatomidae). Brazilian Journal of Biology, São Carlos, v. 63, n. 4 , p. 655-664, 2003.

DOI: $10.1590 / \mathrm{S} 1519-69842003000400012$.

CHOCOROSQUI, V. R.; PANIZZI, A. R. Impact of cultivation systems on Dichelops melacanthus (Dallas) (Heteroptera: Pentatomidae) population and damage and its chemical control on wheat. Neotropical Entomology, Londrina, v. 33, n. 4, p. 487-492, 2004.

DOI: $10.1590 / \mathrm{S} 1519-566 \mathrm{X} 2004000400014$.

CRUZ, I.; BIANCO, R. Manejo de pragas na cultura de milho safrinha. In: SEMINÁRIO NACIONAL DE MILHO SAFRINHA, 6.; CONFERÊNCIA NACIONAL DE PÓSCOLHEITA, 2.; SIMPÓSIO EM ARMAZENAGEM DE GRÃOS DO MERCOSUL, 2., 2001, Londrina. Valorização da produção e conservação de grãos no Mercosul: resumos e palestras. Londrina: IAPAR, 2001. p. 79-112.

DUARTE, M. M.; ÁVILA, C. J.; SANTOS, V. Danos e nível de dano econômico do percevejo barriga-verde na cultura do milho. Revista Brasileira de Milho e Sorgo, Sete Lagoas, v. 14, n. 3, p. 291-299, 2015. DOI: 10.18512/1980-6477/rbms.v14n3p291-299.

FERREIRA, D. F. Sisvar: a guide for its Bootstrap procedures in multiple comparisons. Ciência e Agrotecnologia, Lavras, v. 38, n. 2, p. 109-112, 2014. DOI: $10.1590 /$ S1413-70542014000200001.

GOMEZ, S. A. Controle químico do percevejo Dichelops (Neodichelops) melacanthus (Dallas) (Heteroptera: Pentatomidae) na cultura do milho safrinha. Dourados: Embrapa-CPAO, 1998. 5 p. (Embrapa-CPAO. Comunicado Técnico, 44).

GRAZIA, J. Revisão do gênero Dichelops Spinola, 1837 (Heteroptera, Pentatomidae, Pentatomini). Iheringia. Série Zoologia, Porto Alegre, v. 53, p. 3-119, 1978.

HORI, K. Possible causes of disease symptoms resulting from the feeding of phytophagous Heteroptera. In: SCHAEFER, C. W.; PANIZZI, A. R. (Ed.). Heteroptera of economic importance. Boca Raton: CRC, 2000. p. 1135. DOI: $10.1201 / 9781420041859 . \operatorname{ch} 2$.
MANFREDI-COIMBRA, S.; SILVA, J. J.; CHOCOROSQUI, V. R.; PANIZZI, A. R. Danos do percevejo barriga-verde Dichelops melacanthus (Dallas) (Heteroptera: Pentatomidae) em trigo. Ciência Rural, Santa Maria, v. 35, n. 6, p. 1243-1247, 2005. DOI: $10.1590 / \mathrm{S} 0103-84782005000600003$.

MARTINS, G. L. M.; TOSCANO, L. C.; TOMQUELSKI, G. V.; MARUYAMA, W. I. Controle químico do percevejo barriga-verde Dichelops melacanthus (Hemiptera: Pentatomidae) na cultura do milho. Arquivos do Instituto Biológico, São Paulo, v. 76, p. 475-478, 2009.

MARTINS, G. L. M.; TOSCANO, L. C.; TOMQUELSKI, G. V.; MARUYAMA, W. I.; MACHADO, J. R.; VELOSO, E. S.; GONZAGA, R. L.; CASTRO, J. M. Controle de Dichelops melacanthus (Hemiptera: Pentatomidae) e Dalbulus maidis (Hemiptera: Ciccadelidae) na cultura do milho em Cassilândia (MS). In: CONGRESSO BRASILEIRO DE ENTOMOLOGIA, 21., 2006, Recife. Resumos. Recife: SEB, 2006. p. 697.

MARTINS, J. C.; WEBER, L. F. Imidacloprid no tratamento de sementes associado ou não a pulverizações com inseticidas no controle de Dichelops furcatus (Fabr.) na cultura do milho. In: CONGRESSO NACIONAL DE MILHO E SORGO, 22., 1998, Recife. Resumos. Recife: Associação Brasileira de Milho e Sorgo, 1998.

NETTO, J.; MICHELOTTO, M. D.; GRIGOLLI, J. F. J.; GALLI, J.A.; PIROTTA, M. Z.; BUSOLI, A. C. Damages caused by Dichelops melacanthus (Heteroptera: Pentatomidae) in conventional and transgenic corn hybrids. Bioscience Journal, Uberlândia, v. 31, n. 4, p. 1092-1101, 2015.

DOI: $10.14393 / B J-v 31 n 4 a 2015-26323$.

PANIZZI, A. R. Entomofauna changes with soybean expansion in Brazil. In: WORLD SOYBEAN RESEARCH CONFERENCE, 5., 1994, Chiang Mai. Soybean feeds the world: proceedings. Bangkok: Kasetsart University Press, 1997. p. 166-168.

PANIZZI, A. R.; DUO, L. J. S.; BORTOLATO, N. M.; SIQUEIRA, F. Nymph developmental time and 
survivorship, adult longevity, reproduction and body weight of Dichelops melacanthus (Dallas) feeding on natural and artificial diets. Revista Brasileira de Entomologia, Curitiba, v. 51, n. 4, p. 484-488, 2007. DOI: $10.1590 / \mathrm{S} 0085-56262007000400013$.

ROZA-GOMES, M. F.; SALVADORI, J. R.; PEREIRA, P. R. V. S.; PANIZZI, A. R. Injúrias de quatro espécies de percevejos pentatomídeos em plântulas de milho. Ciência Rural, Santa Maria, v. 41, n. 7, p. 1115-1119, 2011. DOI: $10.1590 / \mathrm{S} 0103-84782011005000081$.
SLANSKY, J. R.; PANIZZI, A. R. Nutritional ecology of seed-sucking insects. In: SLANSKY, J. R.; RODRIGUEZ, J. G. (Ed.). Nutritional ecology of insects, mites, spiders, and related invertebrates. New York: John Wiley \& Sons, 1987. p. 283-320.

VIANA, P. A.; CRUZ, I.; OLIVEIRA, L. J.; CORREAFERREIRA, B. S. Manejo de pragas em agroecossistemas sob plantio direto. Informe Agropecuário, Belo Horizonte, v. 22, n. 208 , p. $63-72,2001$. 